\title{
NUCLEAR ABNORMALITIES IN ERYTHROCYTES AND MORPHOMETRIC INDEXES IN THE CATFISH Cathorops spixii (ARIIDAE) FROM DIFFERENT SITES ON THE SOUTHEASTERN BRAZILIAN COAST
}

\author{
Juliana de Souza Azevedo ${ }^{1}$, Elisabete de Santis Braga ${ }^{2}$ and Ciro Alberto Oliveira Ribeiro \\ ${ }^{1}$ Instituto de Pesquisas Energéticas e Nucleares \\ Centro de Química e Meio Ambiente (CQMA) \\ (Av. Lineu Prestes, 2242, Cidade Universitária, São Paulo, SP, Brasil) \\ ${ }^{2}$ Instituto Oceanográfico da Universidade de São Paulo \\ (Praça do Oceanográfico, 191, 05508-120 São Paulo, SP, Brasil) \\ Corresponding author: julianaazevedo_1978@yahoo.com.br
}

\begin{abstract}
A B S T R A C T
Nuclear abnormalities in erythrocytes (NAE) were taken as biomarkers in the catfish Cathorops spixii (Ariidae) sampled in an estuary little affected by human activity (Cananéia) and in three regions (Santos Channel: SC, Santos Bay: SB and São Vicente Channel: SVC) of the Santos-São Vicente estuary impacted by various anthropogenic activities. Increases in NAE were observed in fish from SC and SVC sampled in the summer period as compared with specimens from the Cananéia estuary. These results suggest the presence of genotoxic compounds in these regions. However, the absence of significant differences in micronuclei frequency reflects slight mutagenic effects in these individuals. It is possible that the lower NAE frequency in specimens from SB might be associated with the greater remobilization and dilution of chemicals in this region. The low frequency of NAE in C. spixii from the Cananéia estuary is in accordance with the slight anthropogenic influence in this system, and may be suggestive of the absence of genotoxic and mutagenic effects in these organisms.
\end{abstract}

\section{RESUMO}

Alterações nucleares eritrocitárias (ANE) foram consideradas como biomarcadores nos bagres Cathorops spixii (Ariidae) amostrados em um estuário com baixa influência humana (Cananéia) e em três regiões (Canal de Santos: CS, Baía de Santos: BS e Canal de São Vicente: CSV) no estuário de Santos-São Vicente, impactado por diversas atividades antropogênicas. Aumentos nas ANE foram observados nos peixes amostrados no CS e CSV durante o período de verão, quando comparados com os espécimes do estuário de Cananéia. Estes resultados sugerem a presença de compostos genotóxicos nessas regiões. Entretanto, ausência de diferenças significativas na frequiência de micronúcleos refletem baixos efeitos mutagênicos nesses indivíduos. As menores frequiências de ANE nos espécimes amostrados na BS podem estar associado à maior remobilização e diluição dos compostos químicos na região. A baixa frequiência de ANE em C. spixii do estuário de Cananéia corrobora a menor influência antropogênica nesse sistema, e pode estar sugerindo ausência de efeitos genotóxicos e mutagênicos nos organismos.

Descriptors: Nuclear abnormalities, Genotoxicy, Biomonitoring, Estuaries, Catfish, Cathorops spixii. Descritores: Alterações nucleares, Genotoxicidade, Biomonitoramento, Estuários, Bagres, Cathorops spixii.

\section{INTRODUCTION}

The interference of toxic compounds in DNA integrity and the formation of nuclear abnormalities are highly useful in investigation into the effects of pollutants on aquatic organisms. According to many authors, biomarkers such as chromosomal aberration, micronuclei formation and other nuclear abnormalities in erythrocytes present a high specificity to pollutants such as toxic metals and PAHs, in biomonitoring studies (MINISSI et al., 1996; BOMBAIL et al., 2001; OBE et al., 2002; CESTARI et al., 2004; FERRARO et al., 2004; HOSHINA et al., 2008; RAMSDORF et al., 2008; MARQUES et al., 2009). Particularly nuclear abnormalities, such as the presence of micronuclei in erythrocytes, represent a highly significant genotoxic effect (BOMBAIL et al., 2001; GUILHERME et al., 2008; MARQUES et al., 
2009). Micronucleus and other nuclear abnormality data betray the presence of clastogenic and aneugenic compounds in the aquatic environment and can indicate a potential risk to the biota (GUILHERME et al., 2008; HOSHINA et al., 2008).

Nuclear abnormalities in erythrocytes have been used in biomonitoring programs to detect genotoxic effects and DNA damage in fish (MINISSI et al. 1996; HAYASHI et al. 1998; AYLLON; GARCIA-VAZQUEZ, 2000; $\quad$ GRISOLIA; STARLING, 2001; ÇAVAS; ERGENEGÖZÜKARA 2005). Abnormal morphological forms of erythrocytes are effective indicators of cytotoxicity. Additionally, the analysis of nuclear abnormalities is described as an efficient cytogenetic technique due to its ample sensitivity to cytotoxic effects on cells of individuals exposed to pollutants (ÇAVAS; ERGENE-GÖZÜKARA 2005).

Cathorops spixii (Ariidae) has wide geographical distribution along the Atlantic coast of South America, from Belize to the Brazilian Southeast. It is, further, the most common catfish on the Brazilian coast (TIJARO et al., 1998). These fish have a benthic habitat and feed mainly on the pelitic fraction in which the bioavailability of contaminants is highest. There are very few studies on the accumulation in and effects of organic pollutants on Cathorops spixii. Some authors have demonstrated the capacity of the species in question to serve as a bioindicator species of metal pollution, more specifically of $\mathrm{Hg}, \mathrm{Co}, \mathrm{Fe}, \mathrm{Se}$ and $\mathrm{Zn}$, in Santos Bay (FARIAS et al., 2005; AZEVEDO et al., 2009a; AZEVEDO et al., 2009b).

The Santos-São Vicente estuary is located in the southeastern coastal region of São Paulo State $\left(24^{\circ} 00^{\prime} \mathrm{S} ; \quad 46^{\circ} 21^{\prime} \mathrm{W}\right)$, Brazil. This region is characterized by a heavy rainy season. Industrial activity is highly developed and the tourist trade is another important economic activity. Santos has the largest commercial harbor in South America and is one of the most important petrochemical and metallurgical industrial areas in Brazil, including the Cubatão industrial complex, home to around 1100 factories. The spread of urbanization and industrialization around the estuary has taken place mainly during the last 50 years, and has been responsible for the degradation of the mangrove vegetation, the emission of industrial effluents and the discharge of domestic sewage and solid wastes into the aquatic system. All these anthropogenic sources of pollution contribute directly or indirectly to the input of contaminants to the estuary. On the other hand, the Cananéia estuarine-lagoon complex, located on São Paulo State's southern coast $\left(25^{\circ} \mathrm{S} ; 48^{\circ} \mathrm{W}\right)$ is considered a preserved region with very low human activity. The inner section of the estuarine-lagoon complex is subject to tidal cycles and to freshwater inputs while drift currents are found externally. The tidal movements and the freshwater discharges define the general hydrological circulation and the water mixture in this estuarine-lagoon complex.

The aim of this present study was to evaluate the occurrence of nuclear abnormalities in erythrocytes of the benthic fish $C$. spixii from sites variously affected by anthropogenic activities on the southeastern Brazilian coast. The tropical catfish $C$. spixii was chosen for this purpose due its capacity to bioaccumulate toxic metals and because of its benthic behavior that ensures its proximity to the most polluted reservoir in the estuarine system. In the present study, mercury was the trace metal investigated.

\section{Material and Methods}

\section{Sampling}

Individuals of $C$. spixii were collected both in the Cananéia estuarine-lagoon complex $(n=140)$ and in the Santos-São Vicente estuarine system ( $\mathrm{n}=$ 81) from the R/V Albacora using a bottom Otter Trawl (1.6" mesh wall and 1.2" mesh cod end) of $11 \mathrm{~m}$ length, set at $8.8 \mathrm{~m}$ depth, in Winter 2005 and Summer 2006. Three sites with distinct pollutant inputs within the Santos/São Vicente estuarine system (San) and with the following characteristics were considered in this study (Fig. 1):

Site 1. Santos Channel (SC): inner part of the system impacted by intense industrial activity. Site 2. Santos Bay (SB): less impacted by industrial activity but subject to intense circulation processes pomoting the distribution of chemical compounds. Site 3. São Vicente Channel (SVC): region characterized by both mangrove forests and urban occupation. By virtue of the contrast it offers, subject as it is to little anthropogenic influence, the Cananéia estuary (Can) was considered a reference site.

The fish collected were maintained in boxes, in water from the sampling site, constantly aerated, and transported alive to the laboratory and there identified in accordance with Figueiredo and Menezes (1978).

\section{Somatic Indexes}

In the laboratory, the individuals were weighed, their total length measured and their livers dissected and weighed. The condition factor (CF) was calculated as $\mathrm{CF}=\left[\right.$ body weight $(\mathrm{g}) /$ length $\left.(\mathrm{mm})^{3}\right] \mathrm{x}$ 100 and the hepatic somatic index (HSI) was calculated using the formula HSI = [liver weight (g)/body weight] x 100 . 


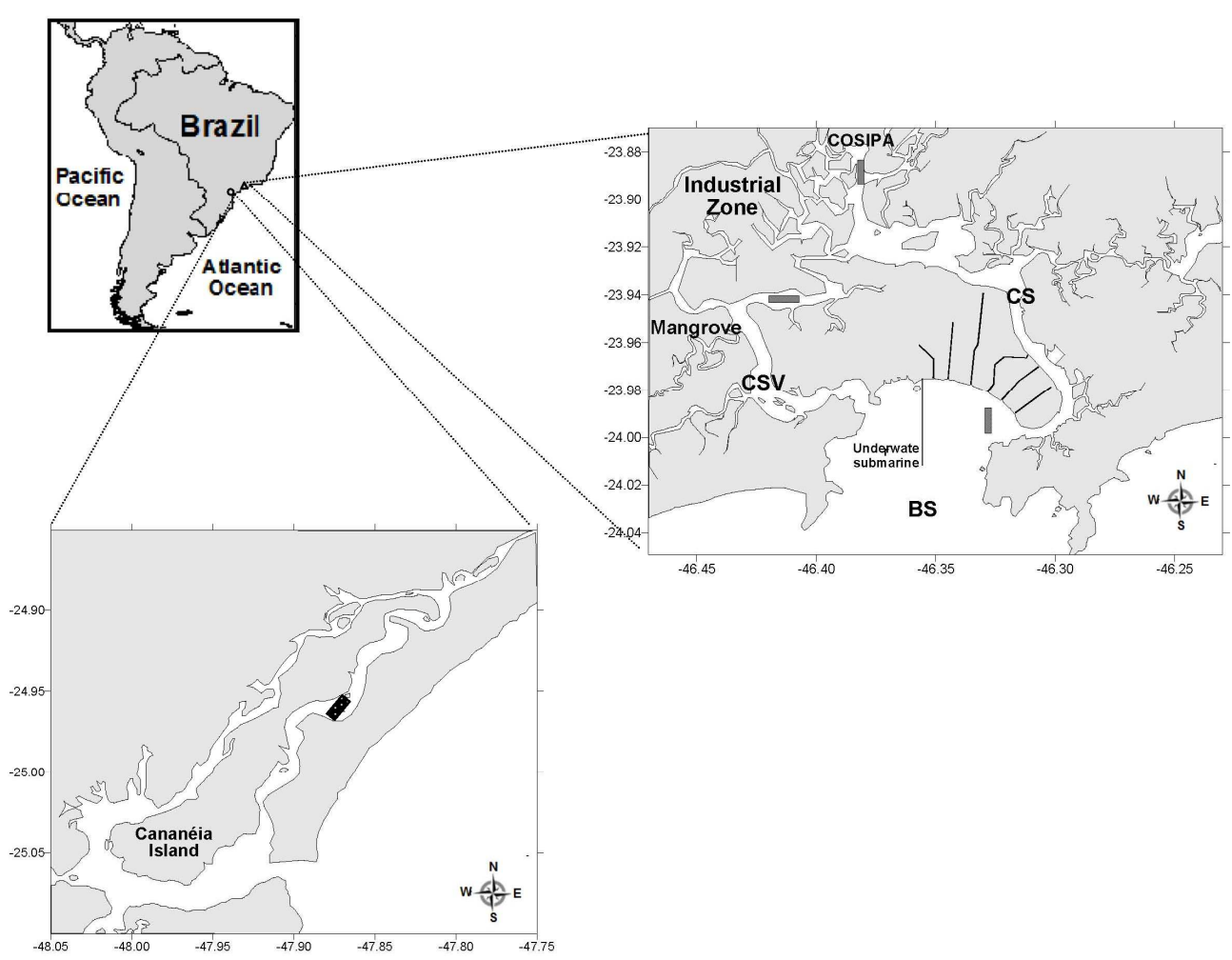

Fig. 1. Localization of sampling sites showing Santos-São Vicente estuarine system and Cananéia estuarine Complex, São Paulo, Brazil.

\section{Slide Procedure}

The blood was sampled and prepared for nuclear abnormality analysis. Slides containing blood smears of $C$. spixii were examined to investigate the presence of micronucleus and other nuclear abnormalities in the circulating erythrocytes. Blood samples were obtained by caudal vein puncture using a syringe without anticoagulant, a drop was immediately smeared on two clear glass slides, air dried, and then fixed in absolute methanol for 10 minutes. Each slide was stained with $10 \%$ Giemsa solution for 30 minutes and 2000 erythrocytes were scored under light microscope with $1000 \mathrm{x}$ magnification to determine the frequency of micronucleus and other nuclear abnormalities. The observed nuclear alterations were classified into categories following Carrasco et al. (1990) and other alterations not classified by Carrasco et al. (op cit.) were classified as "others" (OT), with the following description: "heart" or "clover-leaf" shaped.

\section{Statistical Analysis}

Data of nuclear abnormalities showed a nonnormal distribution. These results are, therefore, presented as median values. Morphometric data and physical and chemical characteristics were expressed as mean \pm standard deviation, minimum and maximum. Differences between the variables were evaluated using non-parametric tests such as KrustalWallis, to compare different areas and different seasonal periods. Mann Whitney was applied for comparison of different annual periods in the same location. The frequencies of each nuclear lesion were expressed per 2000 cells observed and $p$-value $<0.05$ was considered for statistical significance.

\section{RESULTS}

Somatic Indexes

Table 1 gives the mean values of total length, weight, hepatic somatic index (HSI) and condition factor $(\mathrm{CF})$ of $C$. spixii captured during the summer and winter in Cananéia and in three regions of the Santos-São Vicente estuary. Fish from SC and SB sites showed higher values of total length and weight $(p<0.05)$. With the exception of individuals sampled in $\mathrm{SC}$ in the summer, no statistically significant differences in CF were observed. Neither was any significant differences observed in HSI values for fish collected at any of the sites. 
Nuclear Abnormalities in Erythrocytes

The nuclear abnormality analysis of erythrocytes (NAE) of $C$. spixii showed a significantly higher frequency of alterations including Notched, Lobed, and Vacuolizated nuclei (Fig. 2), while fish from Cananéia estuary showed a lower frequency of NAE than those from the study areas in the Santos-São Vicente estuary. In general, significant seasonal differences $(p<0.05)$ were observed for vacuolizated and notched nuclei (Table 2) for all the study sites in the Santos-São Vicente estuary. When compared with individuals from the Cananéia estuary, significant differences were found only in specimens from the SVC site in both periods and for fish from the SC site in the summer period (Table 2).

A low frequency of micronucleus was observed in the specimens from SB, SC and SVC sites in the winter period. This abnormality was, further, not found in individuals from the Cananéia estuary in either period nor at the sites studied in the Santos-São Vicente estuary in the summer (Table 2). In brief, alterations such as the Lobed and Notched presented a higher frequency in both estuaries while vacuolizated nucleus was found as the most frequent nuclear disturbance at the SVC site.

\section{Discussion}

The high population density typical of coastal environments and the use of fertilizers and fossil fuels have increased the concentration of nutrients in water, while the organic (PAHs, OCs and $\mathrm{PCBs}$ ) and inorganic (metals such as $\mathrm{Hg}, \mathrm{Cd}, \mathrm{Pb}, \mathrm{Zn}$ ) pollutants have increased their concentrations in water, sediment and aquatic organisms (LACERDA, 1998; BIANCHI, 2007). Metallic contaminants such as $\mathrm{Hg}$, PAHs, PCBs and nutrient enrichment were found to be more significant in the inner area of the Santos-São Vicente estuary (HORTELLANI, et al.; BICEGO et al. 2006).
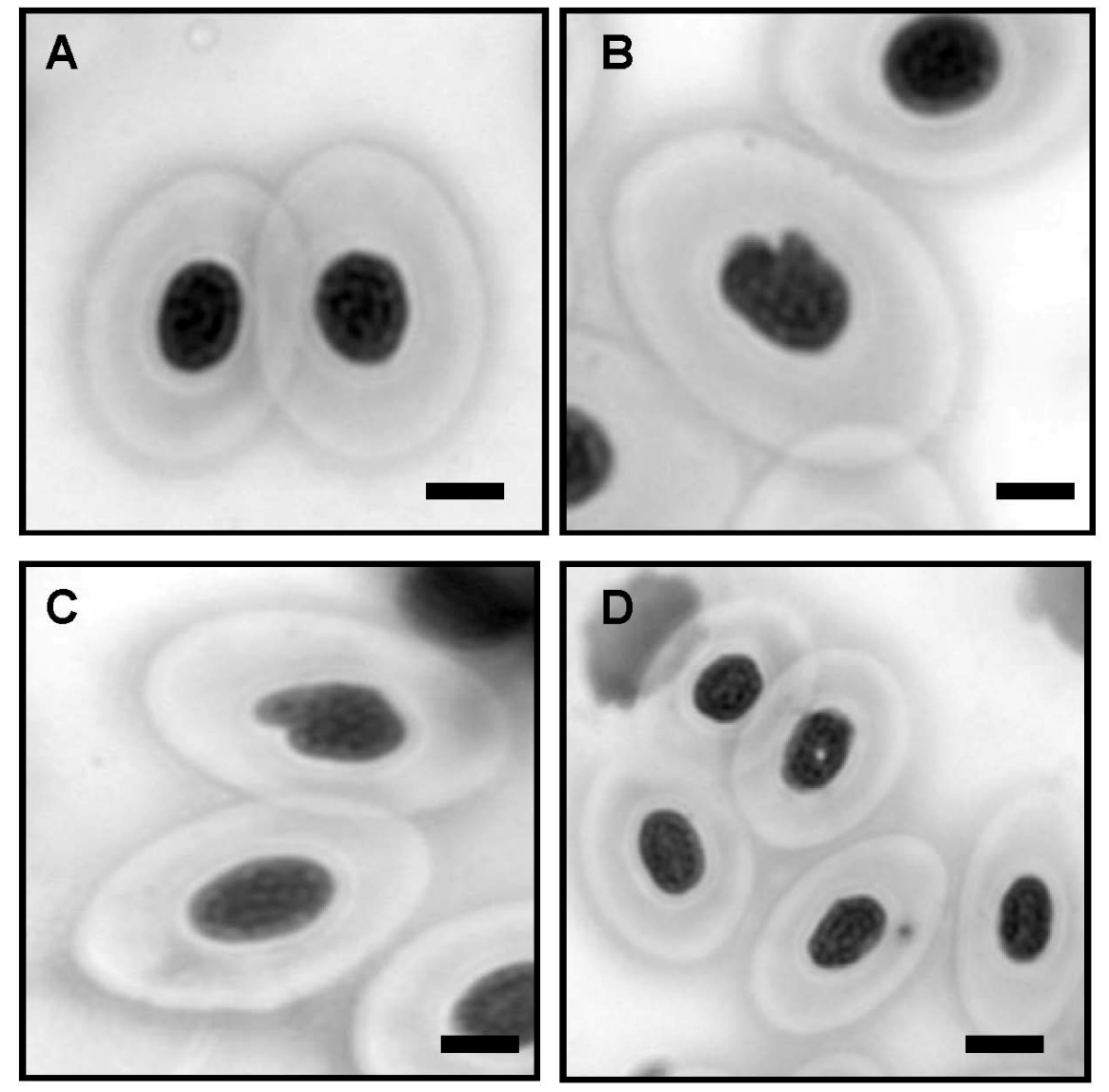

Fig. 2. Cathorops spixii erythrocytes.(A) Normal; (B) Notched. Note a deep notch in a nucleus; (C) Lobed. Note the nuclear surface with lobes. (D) Vacuolizated and micronucleous. Bar $=50 \mu \mathrm{m}$. 
Higher total mercury $(\mathrm{THg})$ concentrations were found in sediments, by Azevedo et al. (2011), in inner areas of the Santos-São Vicente estuary and lower levels of this metal towards the Santos Bay. This profile suggests more intense deposition processes in SC and SVC sites but low deposition and high remobilization of chemicals at the SB site. In relation to nutrients and dissolved oxygen (Table 3), it was possible to confirm the differences between the regions within the estuaries and between the seasons. Therefore, in general, water chemistry and mercury data confirmed intense human influence in the SantosSão Vicente estuary. The THg data together with those for nutrients, $\mathrm{pH}$ and $\mathrm{OD}$ (Table 3 ) reinforce the view that this system needs constant biomonitoring. In the Cananéia estuary, the $\mathrm{THg}$ concentrations were below the TEL limit of $130 \mathrm{ng} \mathrm{g}^{-1}$ (ENVIRONMENT CANADA, 1990), indicating low anthropogenic impact in the region. These environmental data support the biological explanation of the abnormalities found in fish.

Fish from polluted environments usually show an increase in the HSI (ADAMS; RYON, 1994; KARELS et al., 1998) and decreases in the CF, while higher CF values may reflect better adaptation to the environment (ADAMS; RYON 1994; KARELS et al., 1998). In this study, no significant differences were found in these indexes in C. spixii from Cananéia and the sites within Santos-São Vicente. These profiles can be explained, in part, by the sampling of fish with similar biological characteristics (e.g., length, age, maturation, and others).

The nuclear abnormalities considered in this present study have been studied extensively in aquatic organisms such as fish in biomonitoring programs in which genotoxic studies have been integrated into the focus of the investigation (CARRASCO et al., 1990; AL-SABTI; METCALFE, 1995; PACHECO SANTOS, 1996; GRISOLIA; STARLING， 2001; PORTO et al., 2005; UDROIU, 2006). Many authors have described the intensive and continuous industrial and domestic effluent discharge into the Santos-São Vicente estuary, identifying high concentrations of $\mathrm{PAH}, \mathrm{PCB}$, trace metals and nutrient enrichment such as nitrogen and inorganic phosphate (HORTELLANI et al., 2005; BICEGO et al., 2006; AZEVEDO, 2009b). Pollutants such as PAHs and mercury can increase the number of micronucleous and other nuclear abnormalities in fish (PORTO et al., 2005). Additionally, other authors (TORRES DE LEMOS et al., 2007) also consider the micronucleous and other nuclear abnormalities detected in exposed fish as due to mutagenic agents and industrial sewage.

In the present study a higher frequency of nuclear abnormalities in erythrocytes of $C$. spixii was found in specimens from the SC and SVC sites, thus corroborating the results of the other studies described above. In comparison with the data on $C$. spixii from the reference site, the results from the study sites in the Santos-São Vicente estuary indicate the presence of genotoxic compounds due to the intense industrial activities performed in the proximity of the SC and SVC sites. The literature takes into consideration the greater capacity of chemical compound retention in sediments (LACERDA, 1998). The smaller values of nuclear abnormalities observed in fish from the BS site can be associated with the depurative capacity present in this region due to the greater dilution capacity of the pollutants resulting from the process of circulation.

Table 3. Hydrochemical data and total mercury $(\mathrm{THg})$ concentration in sediment from Cananéia estuary (Can) and within different areas in the Santos-São Vicente estuary (SC: Santos channel; SB: Santos Bay; SVC: São Vicente channel). Data are expressed as mean, maximum and minimum in parenthesis (adapted from Azevedo et al. 2009b; Azevedo et al. 2011).

\begin{tabular}{|c|c|c|c|c|c|c|c|}
\hline Region & pH & DO & P-PO ${ }_{4}^{-3}$ & $\mathrm{~N}-\mathrm{NO}_{3}{ }^{-}$ & $\mathrm{N}-\mathrm{NO}_{2}{ }^{-}$ & $\overline{\mathrm{N}}-\mathrm{NH}_{4}{ }^{+}$ & THg \\
\hline & \multicolumn{7}{|l|}{ Winter } \\
\hline Can & $\begin{array}{l}7.84 \\
(7.54-8.10)\end{array}$ & $\begin{array}{l}4.76 \\
(4.42-4.98)\end{array}$ & $\begin{array}{l}1.30 \\
(0.77-1.94)\end{array}$ & $\begin{array}{l}0.19 \\
(0.14-0.29)\end{array}$ & $\begin{array}{l}0.93 \\
(0.56-1.83)\end{array}$ & $\begin{array}{l}2.73 \\
(2.25-3.67)\end{array}$ & $*<16$ \\
\hline SC & $\begin{array}{l}7.92 \\
(7.80-8.08)\end{array}$ & $\begin{array}{l}3.61 \\
(3.12-4.39)\end{array}$ & $\begin{array}{l}4.48 \\
(1.87-7.01)\end{array}$ & $\begin{array}{l}0.93 \\
(0.11-1.97)\end{array}$ & $\begin{array}{l}4.22 \\
(0.58-8.85)\end{array}$ & $\begin{array}{l}10.47 \\
(6.16-14.54)\end{array}$ & $\begin{array}{l}262 \\
(79-413)\end{array}$ \\
\hline SB & $\begin{array}{l}8.22 \\
(8.16-8.25)\end{array}$ & $\begin{array}{l}4.15 \\
(3.88-4.71)\end{array}$ & $\begin{array}{l}1.25 \\
(0.55-3.10)\end{array}$ & $\begin{array}{l}0.09 \\
(0.03-0.14)\end{array}$ & $\begin{array}{l}0.20 \\
(0.03-0.58)\end{array}$ & $\begin{array}{l}3.30 \\
(1.62-2.92)\end{array}$ & $\begin{array}{l}65 \\
(53-91)\end{array}$ \\
\hline \multirow[t]{2}{*}{ SVC } & $\begin{array}{l}7.55 \\
(7.48-7.65)\end{array}$ & $\begin{array}{l}3.18 \\
(3.01-3.36)\end{array}$ & $\begin{array}{l}6.26 \\
(5.13-7.87)\end{array}$ & $\begin{array}{l}0.35 \\
(0.31-0.41)\end{array}$ & $\begin{array}{l}1.36 \\
(0.96-1.48)\end{array}$ & $\begin{array}{l}23.20 \\
(20.55-24.86)\end{array}$ & $\begin{array}{l}192 \\
(43-533)\end{array}$ \\
\hline & \multicolumn{7}{|l|}{ Summer } \\
\hline Can & $\begin{array}{l}7.83 \\
(7.50-8.09)\end{array}$ & $\begin{array}{l}3.82 \\
(3.35-4.01)\end{array}$ & $\begin{array}{l}1.77 \\
(1.10-2.70)\end{array}$ & $\begin{array}{l}0.17 \\
(0.07-0.35)\end{array}$ & $\begin{array}{l}0.11 \\
(0.09-0.17)\end{array}$ & $\begin{array}{l}1.38 \\
(0.79-2.12)\end{array}$ & $\begin{array}{l}38 \\
(30-49)\end{array}$ \\
\hline SC & $\begin{array}{l}8.01 \\
(7.78-8.41)\end{array}$ & $\begin{array}{l}2.73 \\
(1.67-4.75)\end{array}$ & $\begin{array}{l}5.37 \\
(1.15-8.30)\end{array}$ & $\begin{array}{l}21.81 \\
(1.13-31.69)\end{array}$ & $\begin{array}{l}4.44 \\
(0.25-8.13)\end{array}$ & $\begin{array}{l}14.42 \\
(2.10-24.52)\end{array}$ & $\begin{array}{l}247 \\
(185-372)\end{array}$ \\
\hline SB & $\begin{array}{l}8.31 \\
(8.22-8.39)\end{array}$ & $\begin{array}{l}3.95 \\
(3.29-4.45)\end{array}$ & $\begin{array}{l}1.12 \\
(0.83-1.74)\end{array}$ & $\begin{array}{l}5.47 \\
(3.80-6.45)\end{array}$ & $\begin{array}{l}1.38 \\
(0.63-2.63)\end{array}$ & $\begin{array}{l}4.93 \\
(0.32-14.06)\end{array}$ & $\begin{array}{l}55 \\
(27-83)\end{array}$ \\
\hline SVC & $\begin{array}{l}7.39 \\
(7.21-7.63)\end{array}$ & $\begin{array}{l}1.31 \\
(1.09-1.62)\end{array}$ & $\begin{array}{l}5.09 \\
(4.18-5.89)\end{array}$ & $\begin{array}{l}7.52 \\
(5.30-9.95)\end{array}$ & $\begin{array}{l}3.19 \\
(2.16-4.25)\end{array}$ & $\begin{array}{l}38.67 \\
(39.08-44.00)\end{array}$ & $\begin{array}{l}249 \\
(88-532)\end{array}$ \\
\hline
\end{tabular}

* detection limit $=16 \mathrm{ng} \mathrm{g}^{-1}$; DO: dissolved oxygen $\left(\mathrm{mg} \mathrm{L}^{-1}\right), \mathrm{P}_{-} \mathrm{PO}_{4}^{-3}$ : inorganic dissolved phosphorus,

$\mathrm{N}-\mathrm{NO}_{3}{ }^{-}$: nitrate, $\mathrm{N}-\mathrm{NO}_{2}^{-}$: nitrite, and $\mathrm{N}-\mathrm{NH}_{4}{ }^{+}$: ammonium. Nutrients in $\mu \mathrm{M}$. THg: total mercury $\left(\mathrm{ng} \mathrm{g}^{-1}\right)$. 
Table 1. Total length (TL), total weight (TW), hepatic somatic index (HSI) and condition factor (CF) of Cathorops spixii collected from each sampling site. $n$ represents the number of individuals analyzed.

\begin{tabular}{llllcc}
\hline \hline \multicolumn{7}{c}{$\boldsymbol{n}$} & TL $(\mathbf{m m})$ & TW $(\mathrm{g})$ & HSI & CF \\
\hline Winter & & & \\
\hline Can & 51 & $192 \pm 48^{\mathrm{a}}$ & $83 \pm 78^{\mathrm{a}}$ & $1.76 \pm 0.23^{\mathrm{d}}$ & $0.96 \pm 0.09^{\mathrm{d}}$ \\
SC & 17 & $239 \pm 35^{\mathrm{ab}}$ & $138 \pm 97^{\mathrm{ab}}$ & $2.07 \pm 0.28^{\mathrm{d}}$ & $0.91 \pm 0.12^{\mathrm{d}}$ \\
SB & 18 & $149 \pm 28^{\mathrm{a}}$ & $37 \pm 22^{\mathrm{a}}$ & $2.03 \pm 0.52^{\mathrm{d}}$ & $1.04 \pm 0.13^{\mathrm{d}}$ \\
SVC & 18 & $195 \pm 20^{\mathrm{a}}$ & $75 \pm 23^{\mathrm{a}}$ & $1.66 \pm 0.16^{\mathrm{d}}$ & $0.99 \pm 0.06^{\mathrm{c}}$ \\
\hline \multicolumn{7}{c}{} \\
\hline Can & Summer & $157 \pm 22^{\mathrm{a}}$ & $43 \pm 19^{\mathrm{a}}$ & $1.50 \pm 0.32^{\mathrm{d}}$ & $0.92 \pm 0.05^{\mathrm{d}}$ \\
SC & 21 & $226 \pm 34^{\mathrm{b}}$ & $109 \pm 54^{\mathrm{b}}$ & $2.02 \pm 0.38^{\mathrm{d}}$ & $0.83 \pm 0.08^{\mathrm{e}}$ \\
SB & 10 & $284 \pm 29^{\mathrm{b}}$ & $213 \pm 78^{\mathrm{b}}$ & $1.83 \pm 0.50^{\mathrm{d}}$ & $0.91 \pm 0.09^{\mathrm{d}}$ \\
SVC & 10 & $192 \pm 28^{\mathrm{a}}$ & $57 \pm 23^{\mathrm{a}}$ & $1.69 \pm 0.38^{\mathrm{d}}$ & $0.91 \pm 0.08^{\mathrm{d}}$ \\
\hline
\end{tabular}

Values are mean \pm sd. Distinct letters indicate significant differences in the sites $(\mathrm{p}<0.05)$.

Table 2. Mean Frequency of erythrocytes $\left(\%_{0}\right)$ with different nuclear abnormalities in C. spixi from Cananéia and from different areas in Santos-São Vicente estuary. Micronuclei $(\mathrm{MN})$, notched nuclei $(\mathrm{N})$, lobed nuclei $(\mathrm{L})$, blebed nuclei $(\mathrm{BN})$, vacuolizated nuclei $(\mathrm{VN})$ or other kind of abnormalities (OT). $n$ represents the number of individuals analyzed.

\begin{tabular}{|c|c|c|c|c|c|c|c|}
\hline & $n$ & MN & $\mathbf{N}$ & $\mathbf{L}$ & B & $\mathbf{V}$ & OT \\
\hline & \multicolumn{7}{|c|}{ Winter } \\
\hline Can & 60 & $0.0^{\mathrm{c}}$ & $0.9^{c}$ & $1.1^{\mathrm{bc}}$ & $0.0^{\mathrm{c}}$ & $0.1^{\mathrm{c}}$ & $0.3^{\mathrm{c}}$ \\
\hline SB & 12 & $0.10^{\mathrm{c}}$ & $1.2^{\mathrm{bc}}$ & $2.4^{\mathrm{b}}$ & $0.0^{\mathrm{c}}$ & $0.7^{\mathrm{c}}$ & $1.2^{\mathrm{bc}}$ \\
\hline SC & 17 & $0.06^{\mathrm{c}}$ & $1.8^{\mathrm{b}}$ & $2.4^{\mathrm{b}}$ & $0.2^{\mathrm{c}}$ & $0.6^{\mathrm{c}}$ & $0.3^{\mathrm{c}}$ \\
\hline \multirow[t]{2}{*}{ SVC } & 16 & $0.14^{\mathrm{c}}$ & $3.1^{\mathrm{b}}$ & $4.4^{\mathrm{ab}}$ & $0.4^{\mathrm{c}}$ & $5.5^{\mathrm{a}}$ & $1.1^{\mathrm{bc}}$ \\
\hline & \multicolumn{7}{|c|}{ Summer } \\
\hline Can & 80 & $0.0^{\mathrm{c}}$ & $1.1^{\mathrm{bc}}$ & $2.6^{\mathrm{b}}$ & $0.2^{\mathrm{c}}$ & $0.3^{\mathrm{c}}$ & $0.7^{\mathrm{c}}$ \\
\hline SB & 12 & $0.0^{\mathrm{c}}$ & $3.0^{\mathrm{b}}$ & $3.4^{\mathrm{b}}$ & $0.2^{\mathrm{c}}$ & $1.2^{\mathrm{bc}}$ & $1.2^{\mathrm{bc}}$ \\
\hline SC & 16 & $0.0^{\mathrm{c}}$ & $5.9^{\mathrm{a}}$ & $5.1^{\mathrm{a}}$ & $1.0^{\mathrm{bc}}$ & $1.9^{\mathrm{b}}$ & $0.3^{\mathrm{c}}$ \\
\hline SVC & 08 & $0.0^{\mathrm{c}}$ & $6.5^{\mathrm{a}}$ & $7.3^{\mathrm{a}}$ & $0.3^{\mathrm{c}}$ & $1.8^{\mathrm{b}}$ & $1.7^{\mathrm{b}}$ \\
\hline
\end{tabular}

Values are expressed as median. Distinct letters indicate significan differences in the sites $(\mathrm{p}<0.05)$.

The mechanisms of MN formation, which can be related to entire chromosomes or the fragments resulting from broken chromosomes and their significance are well described in the literature. On the other hand, the use of other nuclear abnormalities in erythrocytes for the evaluation of genotoxic effects in aquatic organisms is still debatable. In recent years, the simultaneous analyses of nuclear abnormalities and micronucleic frequency in erythrocytes have received considerable attention. However, the mechanisms underlying the formation of nuclear abnormalities have not yet been fully explained. Further, various studies have shown that nuclear abnormalities can be induced in response to exposure to genotoxic agents (GUILHERME et al., 2008; HOSHINA et al., 2008; MARQUES et al., 2009).

Çavas and Ergene-Gözükara (2005) consider the induction of Lobed and Blebed nuclear abnormalities as the result of fishes' exposure to vestiges of petroleum. The higher values of these alterations in specimens from the SVC and SC sites are, therefore, reinforced by the chemical sediment retention in these regions, related to its pelitic characteristics associated with the intense industrial activities undertaken in the more internal area of the Santos-São Vicente estuary (AZEVEDO et al., 2011). The frequency of nuclear lesions may be altered by several factors such as erythropoiesis, required time for maturation and lifespan of erythrocytes (UDROIU, 2006).

Azevedo et al. (2009b) have evaluated some such biomarkers as metallothionein (MT), lipid peroxidation and $\delta$-ALAD $(\delta$-aminolevulinate dehydratase) activities in the $C$. spixii from Cananéia and SB, SC and SVC in the Santos-São Vicente estuary in order to compare the biological responses of this species from the two estuaries with distinct anthropogenic influence. The authors consider that the biomarkers evaluated present differences between the areas exposed to anthropogenic influence in the Santos-São Vicente estuarine system as compared with the Cananéia estuary, suggesting that disturbances in the specific cell mechanisms can occur because of the multiple xenobiotics in the Santos-São Vicente estuary. Therefore, in this study, the nuclear abnormality data were in accordance with those on other biomarkers observed in $C$. spixii, thus suggesting the proposal that more attention be given to the control of the disposal of compounds that can potentially induce damage to biota and risks to humans in the area of the Santos-São Vicente estuary.

However, although no specific genotoxic effect can be related to mercury contamination, the greater presence of this metal, especially in the inner area of the Santos-São Vicente estuary, is a strong indication, in the resident species, of their exposure to other toxic metals in the system. In studying its effects in wild and caged specimens of the pelagic fish Liza aurata, mercury contamination was detected both in wild and caged fish, thus corroborating the low micronucleus frequency results obtained in this study. Since several studies have indicated that nuclear abnormalities can be induced in response to exposure to genotoxic agents (GUILHERME et al., 2008; HOSHINA et al., 2008; MARQUES et al., 2009), we would suggest that the nuclear abnormalities observed in this study could be induced by mercury.

Finally, this study provides additional data to be integrated into the existing information on biomarkers in $C$. spixii and offers new evidence as to the impact of human activities, such as industry and domestic sewage disposal, on aquatic systems such as Brazilian coastal estuaries. 


\section{ACKNOWLEDGEMENTS}

This study was supported by the São Paulo State Foundation for the Support of Research FAPESP (Process 2005/50769-2), the Brazilian Agency for Science and Technology - CAPES and the Oceanographic Institute of the University of São Paulo.

\section{REFERENCES}

ADAMS, S. M.; RYON, M. G. A comparison of health assessment approaches for evaluating the effects of contaminant-related stress on fish populations. J. Aquat. Ecosyst. Health, v.3, p. 15-25, 1994.

AL-SABTI, K.; METCALFE, C. D. Fish micronuclei for assessing genotoxicity in water. Mutat. Res., v. 343, p.121-135, 1995.

AYLLON, F.; GARCIA-VAZQUEZ, E., Induction of micronuclei and other nuclear abnormalities in European minnow Phoxinus phoxinus and mollie Poecilia latipinna: an assessment of the fish micronucleus test. Mutat. Res., v. 467, p. 177-186, 2000.

AZEVEDO, J. S.; FERNANDEZ, W. S.; FARIAS, L. A.; FÁVARO, D. I.; BRAGA, E. S. Use of Cathorops spixii as bioindicator of pollution of trace metals in the Santos Bay, Brazil. Ecotoxicol., v. 18, p. 578-586, 2009a.

AZEVEDO, J. S.; SERAFIM, A.; COMPANY, R.; BRAGA, E. S.; FÁVARO, D. I.; BEBIANNO, M.J. Biomarkers of exposure to metal contamination and lipid peroxidation in the benthic fish Cathorops spixii from two estuaries in South America, Brazil . Ecotoxicol., v.18, p.1001-1010, $2009 \mathrm{~b}$

AZEVEDO, J. S.; BRAGA, E. S.; FÁVARO, D. T. I.; PERRETTI, A. R.; REZENDE, C. E.; SOUZA, C. M. M. Total mercury in sediments and in Brazilian Ariidae catfish from two estuaries under different anthropogenic influence. Mar. Pollut. Bull DOI: 10.1016/j.marpolbul.2011.09.015, 2011.

BIANCHI, T.S. Biogeochemistry of Estuaries. New York: Oxford University Press, 2007. $706 \mathrm{p}$

BÍCEGO, M. C.; TANIGUCHI, S.; YOGUI, G. T.; MONTONE, R. C.; SILVA, D. A. M.; LOURENÇO, R. A.; MARTINS, C. C.; SASAKI, S. T.; PELLIZARI, V. H.; WEBER, R. R. Assessment of contamination by polychlorinated biphenyls and aliphatic and aromatic hydrocarbons in sediments of the Santos and São Vicente Estuary System, São Paulo, Brazil. Mar. Pollut. Bull., v. 52, p.1784-1832, 2006.

BOMBAIL, V.; Aw, D.; GORDON, E.; BATTY, J. Application of the comet and micronucleus assay to butterfish (Pholis gunnellus) erythrocytes from the Firth of Forth, Scotland. Chemosphere, v. 44, p.383-392, 2001.

CARRASCO, K. R.; TILBURY, K. L.; MYERS, M. S. Assessment of the Piscine Micronucleus Test as an in situ biological indicator of chemical contaminant effects. Canadian J. Fish. Sci., v. 47, p.2123-2136, 1990.

CESTARI, M. M.; LEMOS, P. M. M.; OLIVEIRARIBEIRO, C. A.; COSTA, J. R. M. A.; PELLETIER, E.; FERRARO, M. V. M.; MANTOVANI, M.S. FENOCCHIO, A. S. Genetic damage induced by thophic doses of lead in the neotropical fish Hoplias malabaricus (Characiformes, Erythrinidae) as revealed by the comet assay and chromosomal aberrations. Genet. Mol. Biol., v. 27, p. 270-274, 2004.

ÇAVAS, T.; ERGENE-GÖZÜKARA, S. Genotoxicity evaluation of metronidazole using the piscine micronucleus test by acridine orange fluorescent staining. Environ. Toxicol. Pharmacol., v. 19, p. 107$111,2005$.

ENVIRONMENT CANADA, Canadian sediment quality Guidelines for the protection of aquatic life. Summary Tables. 1999. < http://www.ec.gc.ca>.

FARIAS, L. A.; AZEVEDO, J.; FÁVARO, D. I. T.; SARAIVA, E. S. B. G. Evaluation of mercury, selenium and methylmercury in fish consumed by Santos Bay Communities, São Paulo, Brasil. In: ENCONTRO NACIONAL DE APLICAÇÕES NUCLEARES, ENAN, 7., Santos, Brazil, 2005. Anais ... v.1, p.1-9, 2005.

FERRARO, M. V. M.; FENOCCHIO, A. S.; MANTOVANI, M. S.; CESTARI, M. M.; OLIVEIRA RIBEIRO, C. A. Mutagenic effects of tributyltin (TBT) and inorganic lead (PbII) on the fish H. malabaricus as evaluated of by using the comet assay, Piscine Micronucleus and chromosome aberrations tests. Genet. Mol. Biol., v.27, p.103-107, 2004.

FIGUEIREDO, J. L.; MENEZES, N. A. Manual de peixes marinhos do sudeste do Brasil. II. Teleostei (1). São Paulo: Universidade de São Paulo, Museu de Zoologia, 1978. $110 \mathrm{p}$.

GRISOLIA, C. K.; STARLING, F. L. R. M. Micronuclei monitoring of fishes from Lake Paranoá, under influence of sewage treatment plant discharges. Mutat. Res., v. 491, p.39-44, 2001.

GUILHERME, S.; VÁlEGA, M.; PEREIRA, M. E.; SANTOS, M. A.; PACHECO, M. Erythrocytic nuclear abnormalities in wild and caged fish (Liza aurata) along an environmental mercury contamination gradient. Ecotoxicol. Environ. Saf., v.70, p.411-421, 2008.

HAYASHI, M.; UEDA, T.; UYENO, K.; WADA, K.; KINAE, N.; SAOTOME, K.; TANAKA, N.; TAKAI, A.; SASAKI, Y. F.; ASANO, N.; SOFUNI, T.; OJIMA, Y. Development of genotoxicity assay systems that use aquatic organisms. Mutat. Res., v. 399, p.125-133, 1998.

HORTELLANI, M. A.; SARKIS, J. E. S.; BONETTI, J.; BONETTI, C. Evaluation of mercury contamination in sediments from Santos - São Vicente Estuarine System, São Paulo State, Brazil. J. Braz. Chem. Society, v. 16, n. 6a, p.1140-1149, 2005.

HOSHINA, M. M.; ANGELIS, D. F.; MARIN-MORALES, M. A. Induction of micronucleus and nuclear alterations in fish (Oreochromis niloticus) by a petroleum refinery effluent. Mutat. Res., v. 656, p. 44 - 48, 2008.

KARELS, A. E.; SOIMASUO, M.; LAPPIVAARA, J.; LEPPANEN, H.; AALTONEN, T.; MELLANEN, P.; OIKARI, A. O. J. Effects of EFC-bleached kraft mill effluent on reproductive steroids and liver MFO activity in populations of pearch and roach. Ecotoxicol., v. 7 , p.123-132, 1998 .

LACERDA, L. D. Trace metals biogeochemistry and diffuse pollution in mangrove ecosystems. Mangrove Ecosystems Occasional Papers No.2. Okinawa, Japan: International Society for Mangrove Ecosystems, 1998. $65 \mathrm{p}$. 
MARQUES, S. M.; ANTUNES, S. C.; PISSARRA, H PEREIRA, M. L.; GONÇALVES, F.; PEREIRA, R. Histopathological changes and erythrocytic nuclear abnormalities in Iberian green frogs (Rana perezi Seoane) from a uranium mine pond. Aquatic Toxicol., v. 91, p.187-195, 2009

MINISSI, S.; CICCOTTI, E.; RIZZONI, M. Micronucleus test in erythrocytes of Barbus plebejus (Teleostei, Pisces) from two natural environments: a bioassay for the in situ detection of mutagens in freshwater. Mutat. Res., v.367, p. 245-251, 1996

OBE, G.; PFEIFFER, P.; SAVAGE, J. R. K.; JOHANNES, C.; GOEDECHE, W.; JEPPESEN, P.; NATARAJAN, A. T.; MARTÍNEZ-LOPEZ, W.; FOLLE, G. A.; DREST, M.E. Chromosomal aberrations: formation, identification and distribution. Mutat. Res., v.504, p.17-36, 2002.

PACHECO, M.; SANTOS, M. A. Induction of micronuclei and nuclear abnormalities in the erythrocytes of Anguilla anguilla $\mathrm{L}$. exposed either to cyclophosphamide or to bleached kraft pulp mil effluent. Fresenius Environ. Bull., v. 5, p.746-751, 1996.

PORTO, J. I. R.; ARAÚJO, C. S. O.; FELDBERG, E. Mutagenic effects of mercury pollution as revealed by micronucleus test on three Amazonian fish species. Environ. Res., v. 97, p.287-292, 2005.
RAMSDORF, W. A.; FERRARO, M. V. M.; OLIVEIRARIBEIRO, C. A.; COSTA, J. R. M.; CESTARI, M. M. Genotoxic evaluation of different doses of inorganic lead ( $\mathrm{PbII}$ ) in Hoplias malabaricus. Environ. Monit. Assess. DOI 10.1007/s10661-008-0566-1, 2008.

SKOOG, D. A.; LEARY, J. L. Principles of instrumental analysis. Fourth Ed. Harcourt Brave College Publishers., 1992. $800 \mathrm{p}$.

TIJARO, R.; RUEDA, M.; SANTOS-MARTINEZ, A. Dinâmica poblacional del chivo mapalé Cathorops spixii em la Ciénaga Grande de Santa Marta y complejo de Pajarales, Caribe Colombiano. Bol. Invest. Mar. Cost., v. 27, p.87-102, 1998.

TORRES DE LEMOS, C.; RÖDEL, P. M.; TERRA, N. R.; D'AVILA de OLIVEIRA, N. C.; ERDTMANN, B. River water genotoxicity evaluation using micronucleus assay in fish erythrocytes. Ecotoxicol. Environ. Safety, v. 66, p.391-401, 2007.

UDROIU, I. The micronucleus test in piscine erythrocytes. Aquat. Toxicol., v. 79, p. 201-204, 2006.

WINKLER, L. W. Ber. Dtsch. Chem. Ges. v. 21, p.28432855,1888 .

(Manuscript received 13 July 2011; revised 19 May 2012; accepted 20 July 2012) 